\title{
Risk factors in the practice of primary care
}

\author{
Factorii de risc în practica asistenţei medicale primare
}

\section{Afilon JOMPAN}

Facultatea de Medicină, Universitatea de Vest „Vasile Goldiş“, Arad, România

\begin{abstract}
Knowing, identifying, quantifying and combating risk factors in the disease belongs predominantly to the family doctor. Measures taken in primary care are known as primary prevention activities aimed at the person, target groups or the general population.
\end{abstract}

Keywords: risk factors, detection, evaluation, control, primary prevention

$\left[\begin{array}{l}\text { REZUMAT } \\ \text { Cunoaşterea, identificarea, cuantificarea şi combaterea factorilor de risc în îmbolnăvire aparțin cu preponde- } \\ \text { rență medicului de familie. Măsurile ce se iau in asistența medicală primară sunt cunoscute ca activități de } \\ \text { prevenție primară ce se adresează persoanei, grupurilor țintă sau populației generale. }\end{array}\right.$

Cuvinte cheie: factori de risc, depistare, evaluare, combatere, prevenție primară

\section{INTRODUCERE}

Medicul de familie, ca medic al persoanei, al familiei, al comunităţii umane pe care o deserveşte, nu este numai un medic ce se ocupă de tratamentul şi îngrijirile acordate persoanelor bolnave, ci şi de apărarea sănătăţii persoanelor sănătoase, a celor aparent sănătoase, ce nu au acuze subiective sau clinice, dar care prezintă condiţii, elemente ce pot determina apariţia bolii, pot favoriza instalarea bolii sau evoluţia bolii spre complicaţii, aceştia fiind factorii de risc.

Medicina familiei trebuie să-şi îndrepte obiectivele tot mai mult spre apărarea sănătăţii şi prevenirea îmbolnăvirilor, iar acest fapt se poate realiza prin reducerea sau înlăturarea factorilor de risc şi prin creşterea factorilor sanogeni - benefici stării de sănătate.

Identificarea şi evaluarea factorilor de risc creează premisele favorabile aplicării măsurilor de prevenţie adecvate ce au ca obiectiv prevenirea îmbolnăvirilor, a apariţiei mai tardive a bolii, o evoluţie fără complicaţii deosebit de grave, o scădere a mortalităţii, o creştere a mediei de viaţă şi o creştere a calităţii vieţii.

Dar sănătatea adeseori reprezintă un echilibru între intervenţia unor factori de risc (adesea multipli) şi o serie de factori ce împiedică apariţia şi evoluţia bolii, denumiţi factori sanogeni. Alterarea sănătăţii poate fi rezultatul prezenţei factorilor de risc şi a ponderii lor, dar şi al scăderii numărului sau valorii factorilor sanogeni.

\section{FACTORI DE RISC}

Factor de risc (FR) reprezintă orice condiţie sau element care poate fi descris sau dovedit prin cercetări statistice, clinice sau experimentale ca putând influenţa, în sensul favorizării, apariţiei unei boli la o persoană sau la o comunitate a evoluţiei bolii spre agravare sau deces. Factor sanogen reprezintă orice condiţie sau 
element care, prin prezenţa sa, contribuie la păstrarea sau îmbunătăţirea stării de sănătate.

Riscul reprezintă o probabilitate crescută statistic de a face o anume boală. în evaluarea riscului, intră o multitudine de condiţii:

- Intensitatea expunerii - ce ne indică concentraţia factorului de risc, exprimată cantitativ în cifre sau calitativ în grad de expunere. Astfel, creşterea valorilor colesterolemiei totale peste 200 mg\% constituie un factor de risc cardiovascular, dar valorile foarte mari (> 300 mg\%) cresc şi mai mult riscul; valorile tensiunii arteriale peste 140/90 mmHg cresc riscul cardiovascular, dar valorile foarte mari (> 180/110 $\mathrm{mmHg}$ ) cresc şi mai mult acest risc.

- Timpul de expunere - este direct proporţional cu creşterea riscului. Astfel, o expunere în ani mulţi într-o mină cu risc silicogen (prezenţa bioxidului de siliciu) creşte riscul minerului de a se îmbolnăvi de silicoză. Fumatul pe perioade lungi de timp creşte riscul de bronşită cronică, cancer al aparatului respirator etc.

- Rezistenţa organismului - în faţa factorului de risc, cu caracteristicile individuale ale fiecărei persoane şi cu mecanismele proprii de adaptare sau de neadaptare, influenţează riscul. Asocierea mai multor factori de risc - prin acţiunea lor cumulată, riscul creşte cu valori ce depind de intensitatea, timpul de acţiune a diferiţilor factori de risc.

Acţiunea antagonică a unor factori de risc sau afactorilor sanogeni poate duce la scăderea riscului.

Trialuri clinice importante au relevat implicarea acestor factori de risc şi, prin urmărirea populaţiei supraveagheate pe perioade de 10-15 ani, au putut aduce medicinei moderne argumente asupra acţiunii unor factori de risc, cuantificarea lor şi riscul pe care-l implică prin stabilirea unor riscograme.

Astfel, pentru bolile cardiovasculare, au fost evaluate riscograme în care este analizată implicarea a 4 factori de risc majori (fumatul, hipertensiunea, hipercolesterolemia şi diabetul zaharat), alături de 2 factori de risc asociaţi nemodificabili (sexul şi vârsta).

Există, de asemenea, factori de risc comuni mai multor boli şi atunci strategia de combatere sau diminuare a riscului, adresată acestor factori, influenţează benefic activitatea de prevenţie în mai multe afecţiuni.

Astfel, fumatul este factor major pentru bolile cardiovasculare, pentru boala neoplazică, pentru bronhopneumopatia cronică obstructivă, dar şi factor asociat de risc pentru accidentele vasculare cerebrale, diabetul zaharat şi malformaţii congenitale.

În funcţie de posibilitatea de influenţare a lor, factorii de risc se împart în factori de risc modificabili şi factori de risc nemodificabili.

\section{FACTORI DE RISC NEMODIFICABILI}

\section{Vârsta}

Este azi unanim recunoscut că vârsta înaintată se asociază cu riscul crescut de a dezvolta mai multe boli cronice. Dar acest lucru nu ne poate face să generalizăm că bolile cronice ar fi rezultatul îmbătrânirii, ci al timpului lung de expunere la prezenţa altor factori de risc. Există o patologie în care vârsta poate constitui un risc; aşa s-au dezvoltat unele specialităţi sau subspecialităţi ce se adresează unei anumite vârste:

- neonatologie

- pediatrie

- medicină şcolară

- medicina adolescenţei

- geriatria

Vârsta reprezintă un factor de risc investigat prin anamneză şi consemnat în fişa pacientului. Fiecare vârstă îşi are patologia sa proprie.

\section{Sexul}

Este, de foarte multe ori, asociat riscului crescut de a face o anumită boală. Afecţiunile respiratorii obstructive (BPOC) sunt mai frecvente la bărbaţi faţă de femei. Lupusul eritematos diseminat (LES) afectează predominant sexul feminin, în perioada de activitate ovariană. Caracteristicile legate de rezistenţa la boală a nounăscuţilor de sex feminin sunt legate de cromozomul $X$. Cum fetiţele au 2 cromozomi $X$, ele sunt cu risc mai scăzut de îmbolnăvire, mai rezistente. Speranţa de viaţă a femeilor este mai mare decât a bărbaţilor.

\section{Factorii genetici}

Sunt recunoscuţi ca având rolul lor în multe afecţiuni cronice, sunt redutabili şi puţin influenţabili la această oră. Ei constituie mai mult un element de susceptibilitate în majoritatea afecţiunilor cronice.

\section{FACTORI DE RISC MODIFICABILI}

\section{Factorul social}

Reprezintă un risc important în apariţia şi evoluţia unor boli. Morbiditatea generală, mortalitatea generală, mortalitatea infantilă, mortinatalitatea au indici semnificativ mai crescuţi la clasele sociale mai jos situate într-o ierarhizare pe trepte sociale şi venit economic. Dar şi mortalitatea pentru anumite afecţiuni cunoaşte riscuri crescute la clasele sociale inferioare (cancer pulmonar, cardiopatie ischemică, accidente cerebrovasculare).

Există un risc crescut pentru anumite afecţiuni denumite şi „,boli sociale“.

a) Structura şi schimbările de gradul II din ciclul vieţii de familie pot determina tulburări şi boli ce se pot 
somatiza sau croniciza dacă nu se intervine prompt pentru îndepărtarea riscului.

b) Profesia poate constitui, prin noxele de la locul de muncă, dar şi prin anumite poziţii legate de ocupaţia respectivă, factori de risc ce pot fi modificaţi sau chiar înlăturaţi.

Recunoaşterea riscului profesional se traduce prin existenţa în legislaţie a „,bolilor profesionale“, cu relaţie directă între profesie, locul de muncă şi boală.

\section{Factorii de mediu}

Factorii de mediu pot fi factori de risc sau factori sanogeni, după caracteristicile lor.

a) Aerul - prin temperatura aerului, umiditate, mişcare, compoziţie şi poluare, poate constitui risc de îmbolnăvire.

b) Apa - constituie unul dintre factorii de mediu ecologic foarte importanţi în desfăşurarea proceselor vitale, condiţionând existenţa şi dezvoltarea fiinţelor vii, dar şi în riscul de îmbolnăvire prin prescripţiile sale fizice, chimice sau biologice sau poluare.

c) Solul comunităţii - reprezintă stratul superficial al scoarţei terestre în care se produc procese fizico-chimice şi organice, cu activitate biologică în care se produce mineralizarea materiei organice. Solul, la nivel comunitar, conţine o structură minerală şi organobiologică vizibilă, în continuă schimbare. Solul reprezintă un factor deosebit de important al mediului ambiant, fiind locul unde se desfăşoară o multitudine de procese fizice, chimice şi biologice ce acţionează asupra omului şi populaţiei comunităţii, influenţând starea de sănătate prin caracteristicile fizice, chimice, biologice şi de poluare.

d) Locuinţa - prin caracteristicile sale, poate fi un factor de risc sau un factor sanogen.

e) Alimentaţia - are o importanţă deosebită pentru sănătatea omului şi a colectivităţilor umane. Aspectul cantitativ şi calitativ al alimentelor influenţează în mod direct sănătatea populaţiei, iar poluarea ei se constituie într-un factor de risc deosebit.

f) Comportamente, obiceiuri şi tradiţii - ca stil de viaţă, pot constitui un risc de îmbolnăvire.

- fumatul constituie un obicei dăunător, devenind factor de risc important în apariţia şi evoluţia: multor afecţiuni.

- consumul exagerat de alcool reprezintă un factor de risc important în diverse afecţiuni somatice: tulburări digestive (gastrită, ulcer, pancreatite, hepatită cronică, ciroză hepatică), boli cardiovasculare (cardiomiopatie etanolică, tulburări de ritm), tulburări neurologice (epilepsie, polinevrită), tulburări psihice (dependenţă fizică şi psihică, delirium tremens), importante probleme de ordin social, familial, profesional, judiciar.
- consumul exagerat de cafea poate fi un factor de risc în apariţia diferitelor tulburări neurovegetative, boli cardiovasculare

- consumul exagerat de sare - unanim recunoscut ca un factor de risc important în apariţia şi evoluţia HTA, a bolilor cardiovasculare

- sedentarismul, ca obicei comportamental, implică un risc crescut de apariţie a obezităţii, a bolilor cardiovasculare, a bolilor aparatului locomotor.

g) Ingestia unor medicamente - pe perioade mai lungi, poate constitui un factor de risc în apariţia unor boli.

\section{DEPISTAREA FACTORILOR DE RISC}

E firesc ca rolul cel mai important în depistarea precoce a factorilor de risc să revină asistenţei medicale primare, care, prin medicul de familie, prin lista de pacienţi înscrişi, să poată face această depistare.

\section{Tipuri de depistare}

Depistarea individuală (screening-ul individual) reprezintă depistarea la o persoană a unui factor de risc.

Depistarea în masă (screening-ul populaţional) constă în efectuarea unui test la totalitatea persoanelor unei comunităţi sau a unui subgrup de persoane (a celor aflate pe lista de pacienţi), în vederea stabilirii abaterilor de la normal, a depistării riscului de boală. Astfel, efectuarea depistării persoanelor cu hipercolesterolemie totală sau a persoanelor ce prezintă hiperuricemie poate constitui un exemplu.

Screening-ul populaţional este indicat a se face atunci când riscul de îmbolnăvire este important, poate evolua asimptomatic şi există un mod eficient de combatere sau tratament. Depistarea ţintită (selectivă) se aplică nu întregii populaţii, ci unui grup populaţional cu risc crescut.

Rezultatele depistării, indiferent de tip, necesită a fi prelucrate statistic, comunicate şi pacienţilor şi urmate obligatoriu de măsuri adecvate de combatere sau diminuare a riscului.

Acţiunile de prevenţie primară rămân în sarcina medicului de familie ca o armă redutabilă, el evidenţiind şi evaluând factorii de risc spre a trece, în etapa următoare, la acţiuni concrete de combatere sau diminuare a lor. El, medicul de familie, e necesar să creadă şi să se implice într-o asemenea activitate de prevenţie, ale cărei rezultate se observă abia după ani de muncă.

Evaluarea riscului în urma unui screening populaţional se face prin calcularea riscului relativ şi a riscului atribuibil, prin introducerea rezultatelor în tabelul de contingenţă (tabel 1). 
TABEL 1. Tabelul de contingență

\begin{tabular}{|l|c|c|c|c|}
\hline & \multicolumn{3}{|c|}{ Boală sau deces } & Total \\
\hline \multirow{4}{*}{ Factor de risc } & & + & - & \\
\cline { 2 - 5 } & + & $\mathrm{a}$ & $\mathrm{b}$ & $\mathrm{a}+\mathrm{b}$ \\
\cline { 2 - 5 } & - & $\mathrm{c}$ & $\mathrm{d}$ & $\mathrm{c}+\mathrm{d}$ \\
\hline Total & & $\mathrm{a}+\mathrm{c}$ & $\mathrm{b}+\mathrm{d}$ & $\mathrm{n}$ \\
\hline
\end{tabular}

a - persoanele care fac boala sau decedează, dintre cei expuşi riscului b - persoanele care nu fac boala, dintre cei expuşi riscului

c - persoanele care fac boala sau decedează, dintre cei neexpuşi riscului

$d$ - persoanele care nu fac boala, dintre cei neexpuşi riscului

$a+b=$ lotul expuşilor

$c+d=$ lotul neexpuşilor

$\mathrm{a}+\mathrm{c}=$ totalul bolnavilor şi decedaţilor

$\mathrm{b}+\mathrm{d}=$ totalul nonbolnavilor

$\mathrm{n}=\mathrm{nr}$. total al subiecţilor studiaţi

R1 = riscul de boală sau deces la cei expuşi, R1 = a/ $(a+b)$

RO = riscul de boală sau deces la cei neexpuşi, RO = c/(c+d)

TABEL 2. Interpretarea rezultatelor

\begin{tabular}{|l|l|l|}
\hline Risc relativ & Risc atribuibil & Interpretare \\
\hline$R R>1$ & $R A>0$ & Factor de risc \\
\hline$R R=1$ & $R A=0$ & Factor indiferent \\
\hline$R R<1$ & $R A<0$ & Factor de protecţie \\
\hline
\end{tabular}

\section{CONCLUZII}

Programele de combatere a riscului de îmbolnăvire necesită a fi programe individuale pentru fiecare pacient expus unor factori de risc, dar benefice dacă ele s-ar efectua într-un program naţional de prevenţie primară.
Conştientizarea individului sau a unui grup populaţional în a-şi modifica stilul de viaţă, felul de a se alimenta în absenţa oricărei suferinţe reprezintă o încercare „temerară“. A schimba modul de viaţă, statutul socioeconomic, nivelul cultural, gradul de informare şi coeziune al familiei, atitudinea prietenilor, rudelor şi colegilor de muncă poate fi o alegere favorabilă sau contrară.

Abilitatea medicului de familie reprezintă însă factorul determinant în adeziunea pacientului la un program. Medicul de familie trebuie să aibă diplomaţia necesară în procesul de negociere şi să-I facă pe pacient partenerul său în lupta pentru apărarea propriei sănătăţi. Programul de combatere a unui cumul de factori de risc nu trebuie început cu "toţi deodată“, ci în trepte, printr-o negociere permanentă cu pacientul. Trebuie ca, la fiecare treaptă, pacientul să aibă certitudinea scăderii riscului şi a preocupării sale pentru o nouă etapă, în a cărei eficienţă crede. Orice tentativă a pacientului de întrerupere sau renunţare la program e necesar să fie combătută, „în lipsa simptomelor", cu exemple concrete de evoluţie nefavorabilă, chiar catastrofală, şi o informare a posibilităţilor la zi de combatere a riscului.

Familia poate fi de un real folos atât în ajutorul dat celui în cauză, cât şi în confirmarea aderenţei la program (renunţarea la fumat şi alcool, mişcarea, dieta).

Conflict of interest: none declared Financial support: none declared

\section{BIBLIOGRAFIE}

1. Jompan A. Medicina familiei, ediţia a X-a. Editura Eurostampa, Timişoara, 2016.

2. Restian A. Bazele medicinei de familie. Editura Medicală, Bucureşti, 2003.

3. Matei D. Esenţialul în medicina de familie, ediţia a III-a. Editura Amaltea, Bucureşti, 2016.

4. Taylor BR. Fundamentals of Family Medicine. Editura Springer, New York, 1996.

5. Jompan A. Manager, lider şi indicatori ai stării de sănătate. Editura Eurostampa, Timişoara, 2010.

6. Jompan A. Asistenţa medicală primară a sănătăţii. Editura Eurostampa, Timişoara, 2016.
7. Harrison. Principii de medicină internă. Editura Orizonturi, Bucureşti, 2012.

8. Ghiduri ESC - Medicină cardiovasculară. Compendiu de ghiduri. Editura Infomedica, Bucureşti, 2015.

9. Karila L. Book des ECN. Editura Medicală Universitară „Iuliu Haţieganu“, Cluj-Napoca, 2011.

10. American Diabetes Association. Standard of medical care in diabetes. Diabetes Care 2005; 3(Suppl 1).

11. Schneider F, Jompan A. Prevenirea şi combaterea bolilor cardiovasculare obiectiv prioritar pentru sănătatea şi prosperitatea naţiunii. Actualitatea Medicală 1995;34.
12. Jompan A. The study of the cardiovascular risk factors in an urban Industrial comunity. Conferinţa de Medicină de Familie, Praga, 2006.

13. Jompan A et al. Traditional nutrition - A risk for cardiovascular diseases in the Banat Region. Szeged, 2011. 